Article

\title{
The Role of Political Connections on Family Firms' Performance: Evidence from Indonesia
}

\author{
Iman Harymawan *(D), Mohammad Nasih, Muhammad Madyan and Diarany Sucahyati \\ Department of Accountancy, Universitas Airlangga, Surabaya 60286, Indonesia; \\ mohnasih@feb.unair.ac.id (M.N.); muhammad_madyan@feb.unair.ac.id (M.M.); \\ diarany.sucahyati-2014@feb.unair.ac.id (D.S.) \\ * Correspondence: harymawan.iman@feb.unair.ac.id; Tel.: +62-819851154
}

Received: 22 May 2019; Accepted: 11 September 2019; Published: 23 September 2019

\begin{abstract}
The purpose of this study is to investigate the relationship of firms with family ownership and their performance in Indonesia and further examine on how political connections affect this relationship. This study used 933 samples from 413 companies listed on the Indonesia Stock Exchange (IDX) in the period between 2014 and 2016. Using ordinary least square (OLS) regression, the results shows that firms without family ownership (non-family firms) have better performance than firms with family ownership (family firms) in Indonesia. Furthermore, the findings also show that the performance of family firms significantly improve when the firms are affiliated with political connections. Our findings imply that establishing political connections in family firms will increase the performance of the firms.
\end{abstract}

Keywords: family firms; political connections; firm performance; emerging countries

JEL Classification: G32; G34

\section{Introduction}

Over the past three decades, research on family firms attract attention from international scholars. One of the most important questions is related to whether family firms have better performance relative to non-family firms. The findings on the relationship between family firms and performance also shows mixed evidence (McConaughy et al. 2001; Naldi et al. 2007; Sraer and Thesmar 2007; Cucculelli and Micucci 2008; Eddleston et al. 2007).

Another stream of literature that has also attracted considerable interest from scholars is about political connections in business. Prior studies have found that firms with political connections have several benefits (lower tax, government procurement, licenses, access to finance, lower cost of debt, higher chance to be bailed out, less restriction on entry into regulated industry etc.) that could support their connected firms (Boubakri et al. 2012; Houston et al. 2014; Adhikari et al. 2006; Wu et al. 2012; Harymawan 2018; Gray et al. 2016; Hung et al. 2017).

However, to our knowledge, only one article has discussed the impact of political connections on the relationship between family firms and firm performance (Muttakin et al. 2015). Investigating the issue of family firms and politics in Indonesia is interesting for several reasons. First, Claessens et al. (2000) found that 68 percent of firms in Indonesia have family-ownership. Given the high percentage of family firms, it is important to analyze the performance of family firms in Indonesia. One example of a family firm in Indonesia is the Ciputra Group. This firm has been listed on the Indonesia Stock Exchange (IDX) since 1994. Up until now, this firm has diversified into 11 industries, including township, office buildings, shopping centers, hotels, apartments, recreational centers, sport facilities, telecommunications, healthcare, brokerage, media and commerce. Second, previous studies have 
shown that Indonesia is a country with high political influence in the context of business (Fisman 2001; Harymawan and Nowland 2016). They found that connected firms in Indonesia affected by the changes of political stability and government effectiveness. Specifically, connected firms provide different financial reporting quality subject to the level of political stability and governmental effectiveness. These findings shows that political connections in Indonesia play an important role on business decision making. However, it remains unknown how political connections affect family firms decision making in Indonesia.

This study extends the literature by examining the role of political connections on the relationship between family firms and a firm's performance in Indonesia. In the 2014, there was a presidential election in Indonesia. At that time, Joko Widodo was appointed as the new President of Indonesia (2014-2019). To avoid the bias of political connections proxy measure due to the possible political power changes around the election, we decided to start our sample period in 2014. Using the firms listed on the Indonesia Stock Exchange from 2014 to 2016, this study obtained a total of 933 firm-year as the final sample. The descriptive statistics revealed that 41 percent and 34 percent of firms in Indonesia are family-owned and politically connected, respectively. Twelve percent (111 out of the 933 observations) of the firms observed have both family-owned and political connections. Despite this number being slightly lower than in the study by Claessens et al. (2000), the findings show that family firms still comprise a major proportion of the Indonesian economy. We used some univariate analyses to check the relationship between the variables. Our correlation matrix showed that family firms have a negative and significant association with performance. However, there was no significant association between political connections and a firm's performance. When we compared the mean between the group of family firms and the group of non-family firms, we found that family firms have a significantly lower mean than the non-family firms. It also shows that family firms have a lower probability of having political connections.

Next, we test the hypotheses using ordinary least square (OLS) regression. Our first model showed that family firms have significantly lower performance compared to non-family firms. We then tested the effect of the involvement of politicians in family businesses on the relationship between family firms and their performance. Interestingly, we found that family firms with political connections demonstrate significantly better financial performance than other firms (family firms without political connections; non-family firms with political connections; and non-family firms without political connections). These findings indicate that political connections potentially provide support to family firms, which increases their performance.

This study contributes to the literature by examining the role of political connections on the performance of family firms in Indonesia. The remainder of this article consists of the literature review, hypotheses development, data and methodology, results, and the conclusion.

\section{Literature Review}

Prior studies have discussed some features that affect the firm performance in Indonesia. Harymawan et al. (2019) finds that more directorships held by the current chief executive officer (CEO) will lead to lower performance of the firms. Ramdani and Witteloostuijn (2010) also find a positive associations between CEO duality and firm performance. Interestingly, they find that board size is a negative moderating of the positive associations between CEO duality and firm performance.

Some prior studies also discussed about family firms in Indonesia Mulyani et al. (2016); Untoro et al. (2017). Some of previous studies also have examined the difference characteristics and outcomes between family and non-family firms. Jara Bertin and Iturriaga (2014) found that higher control from the dominant shareholders (i.e.: family members) resulted in lower earnings. Hategan et al. (2019) examine the relationship between family firms and social responsibility awareness using a Romanian sample. They found that Romanian family firms have greater attention on the current changes in business environment and prepared an internal process strategy to response this changes. Specifically, they are more aware on the sustainability of their business. Wang et al. (2016) also shows that family firms 
are more likely to conduct business transformation and to enter strongly correlative industries and non-regulated industries than non-family firms.

There are two competing arguments on the relationship between family firms and firm performance. Some scholars found that family firms have a better performance than non-family firms. For example, Anderson and Reeb (2003) examined the relation between founding-family ownership and firm performance. They found that family firms perform better than non-family firms, especially when the family member serve as the CEO of the firms. Maury (2006) also investigated the performance of family firms in Western Europe countries. He found that firms which actively controlled by family members lead to better firm performance. He also found that family firms have higher firm valuation.

In contrast, some scholars have found a negative associations between family firms and firm performance. Family firms are potentially facing some problems which could reduce their performance. Benjamin et al. (2016) argued that when a family shareholder has a significant ownership level, the firm has a higher probability to pay a high level of dividend. Furthermore, some firms are also have higher probability to hire a family-related manager even if the individual has a lack of managerial skills (Xu et al. 2015; Beuren et al. 2016). Internal family conflicts can lead to inharmonious relationships within the company and this often ends in disunity (Cheng 2014). In addition, the successor (second/next-generation) tends to destroy the original value (Villalonga and Amit 2006). Sciascia and Mazzola (2008) find that firms with family involvement in management have lower performance. Based on above discussion, we predict there is an associations between family firms and firm performance in Indonesia. The formal hypothesis is as follows:

Hypothesis 1. There is an associations between firms with family ownership (family firms) and firm performance.

Prior studies have discussed the effect of political connections on business in Indonesia. Fisman (2001) investigate the relationship of politically connected firms in Indonesia and stock price market reactions. He uses a health condition of former president of Indonesia, Suharto, as an event to test this relationship. He found that the stock price of politically connected firms in Indonesia dropped significantly when there was a bad news on the health of Suharto. In contrast, when there was good news on Suharto's health condition, the stock price increased significantly. Harymawan and Nowland (2016) showed that the earnings quality of politically connected firms in Indonesia is dependent on the level of political stability and government effectiveness.

Prior literature suggests that political connections can provide prefential benefits to their connected firms Boubakri et al. (2012); Houston et al. (2014); Adhikari et al. (2006); Wu et al. (2012); Harymawan (2018). Boubakri et al. (2012) showed that politically connected firms enjoy a lower cost of equity than non-politically connected firms. Houston et al., also found that firms which hire a director with political ties have a significant lower cost of bank loans. Furthermore, Adhikari et al. (2006) found that firms with political connections in Malaysia pay a significant lower rate of tax. In China, Wu et al. (2012) showed that private firms with politically connected directors pay also pay a lower tax rate. Harymawan (2018) also showed that militarily connected firms (one type of political connections) enjoy a lower loan interest rate in Indonesia.

Based on some benefits earned by politically connected firms, it is expected that political connections could help the connected firms to increase their performance. Niessen and Ruenzi (2010) found that in Germany connected firms have significantly better stock market performance than their non-connected peers. Li et al. (2008) investigated the performance of the firms which owned by private entrepreneurs which join as a political party member in China. They found that these firms perform better than firms owned by private entrepreneurs which do not join a political party. Ding et al. (2014) also find that the state-owned enterprises improves their accounting performance despite they have weakens board independence. Based on the above discussion, we expect that political connections could help family firms to increase their firm performance. Therefore, we propose the formal hypothesis as follow. 
Hypothesis 2. Family firms with political connections will have better firm performance than other firms.

\section{Methodology}

\subsection{Samples and Data Sources}

The initial observations of this study was 1239 firms (413 firms per year) consist of all industries covered on the Indonesia Stock Exchange (IDX) spanning from 2014 to 2016. Based on our first sample selection criteria, we exclude all firms in the financial industry due to the nature of their financial statements. Excluding firms from financial industry from the sample increase the comparability between firms (Sánchez and Yurdagul 2013). Secondly, we also exclude all firms without complete financial data.

The data was obtained from two sources. The first set of data, financial data, was collected from the ORBIS database. The second set of data, non-financial data, was obtained from the annual report, financial reports, and company performance summaries which are available from IDX (Indonesia Stock Exchange) website and or ICMD (Indonesia Capital Market Directory) data. We hand-collected several items of data such as political connections (PCON), family firms (FF), the number of commissioners (COMSIZE) and directors (DIRSIZE), the percentage of independent commissioners (INDCOM), and the percentage of independent directors (INDDIR) from the reports. Finally, we merged these data with the data from ORBIS. As a result, we found 933 firms-year observations as our final sample.

\subsection{Variables Definition}

\subsubsection{Family Firms}

The family firms were measured by the position of director or commissioner being held by more than one member of the same family (marked by the same surname) and by having ownership of at least $5 \%$ of the shares (Zhou et al. 2017). Referring to regulation from Indonesia Financial Service Authority, ${ }^{1}$ it is compulsory for the public firms in Indonesia to disclose the affiliated relationships among director and commissioner within the firms in their annual report. Furthermore, we also did a re-check of each affiliated relationships found in the annual report to confirm the relationship.

\subsubsection{Political Connections}

Political connections (PCON) were measured through the commissioners and directors of companies who were currently or formerly members of parliament (DPR), ministers, heads of state, or those who had close ties with top politicians and/or parties (Faccio 2006). They also had to meet the criteria of PEP (politically exposed person) according to Bank Indonesia Regulation Number $12 / 3 / \mathrm{PBI} / 2010$ 's explanation of article 11 . Based on this regulation, a politically exposed person is defined as "individuals who are or have been entrusted with prominent public functions in either domestically or internationally, for example State Officials as referred to in laws and regulations that governs State Officials, and/or senor politicians that have influence on the party's policies and operations". The data on the political connections were obtained through the profiles of the directors and commissioners of the firms contained in their annual report.

\subsubsection{Firm Performance}

The firm's performance was the dependent variable of this study, measured using Tobin's $Q$ approach which refers to the research conducted by Muttakin et al. (2015). Tobin's Q represents the view of long-term investors because one of its formulae uses the market value of equity. The market

1 Surat Edaran Otoritas Jasa Keuangan Number 30042016. 
value of equity is the accumulation that starts from the firm's long efforts. It is different when compared to ROA, which uses profit as a basis, because ROA also only represents a short period of time (one year).

\section{Result}

The definition of all variables used in this study are available in the Appendix A. All analyses in this study were conducted using STATA software. Figure 1 presents the relation between independent and dependent variables in this study.

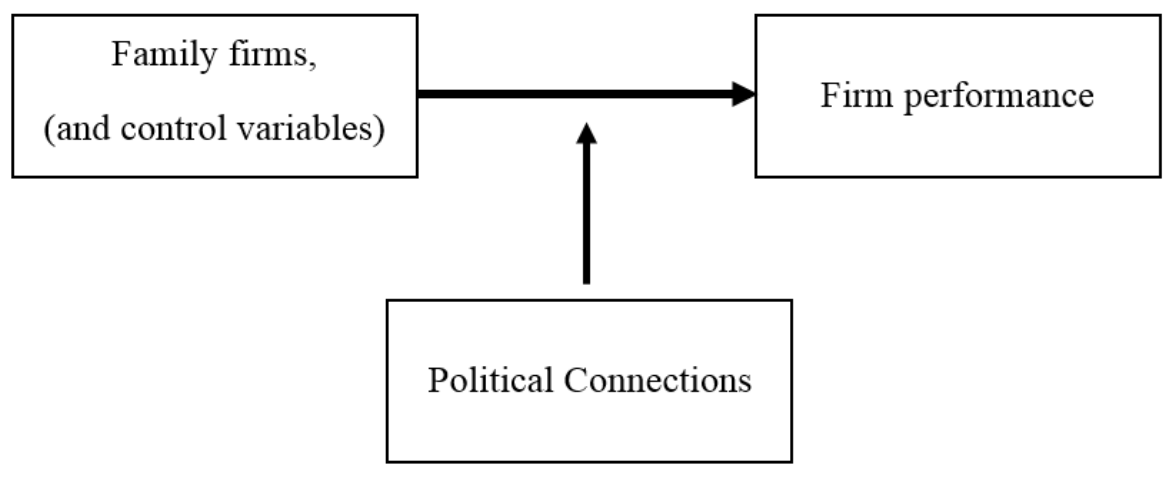

Figure 1. Research framework.

Table 1 provide the details of sample distribution in this study. Panel A presents the comparison of the sample between firms with and without family ownership. It shows that 41 percent of firms in this sample have family ownership in the firm. Manufacturing industry has the highest fraction of family firm in this sample. Panel B presents the comparison between firms with and without political connections. About 39 percent of the firms are politically connected. Wholesale and retail trade is the industry with the highest percentage of firms with political connections. Panel C shows the number of politically connected firms with family ownership. It shows that 111 firms (12 percents) are belongs to this category.

Table 2 presents the descriptive statistics of the variables used in this study. Firm performance was measured by TOBINS_Q, which represents the long-term view of the investor. INDCOM or the percentage of independent commissioners had a maximum value of $100 \%$ because there are several companies whose entire body of commissioners are also independent commissioners.

Figure 2 present the details of the generation of active family firms who serve as directors. Based on the data in Indonesia in the period 2014-2016, it shows that most of the family firms is actively operated by the second generation of the family. Unfortunately, there are many firms that do not disclose this information in detail. Figure 3 shows the distribution of the political connection positions in family firms. Most of the politicians serve as commissionaire in the firm. The independent commissioner position is the highest position, which is more likely to be held by someone with a political connections.

Table 3 presents the comparison of the firm characteristics between firm with and without family ownership. The coefficient of TOBINS_Q is -3.397 and significant at the 1 percent level. This suggests that firms with political connections significantly perform better than non-family firms. The results also shows that family firms in Indonesia are less likely to be politically connected, have smaller size of board commissionaire, smaller firms size, have a lower capital intensity, and lower leverage. 
Table 1. Sample distribution.

\begin{tabular}{|c|c|c|c|c|c|c|c|}
\hline \multicolumn{8}{|c|}{ Panel A Family Firms Sample Distribution $(F F)$} \\
\hline \multirow{2}{*}{ SECTOR (SIC) } & \multirow{2}{*}{ INDUSTRY } & \multicolumn{2}{|c|}{$F F$} & \multicolumn{2}{|c|}{ NON-FF } & \multicolumn{2}{|c|}{ TOTAL } \\
\hline & & $\mathbf{n}$ & $\%$ & $\mathbf{n}$ & $\%$ & $\mathbf{n}$ & $\%$ \\
\hline 0 & Agriculture, Forestry, and Fishing & 16 & $43 \%$ & 21 & $57 \%$ & 37 & $100 \%$ \\
\hline 1 & Mining & 76 & $50 \%$ & 76 & $50 \%$ & 152 & $100 \%$ \\
\hline 2 & Construction Industries & 104 & $46 \%$ & 121 & $54 \%$ & 225 & $100 \%$ \\
\hline 3 & Manufacturing & 50 & $33 \%$ & 102 & $67 \%$ & 152 & $100 \%$ \\
\hline 4 & Transportation, Communication and Utilities & 58 & $36 \%$ & 102 & $64 \%$ & 160 & $100 \%$ \\
\hline 5 & Wholesale and Retail Trade & 36 & $36 \%$ & 65 & $64 \%$ & 101 & $100 \%$ \\
\hline 7 & Services Industries & 36 & $45 \%$ & 44 & $55 \%$ & 80 & $100 \%$ \\
\hline \multirow[t]{2}{*}{8} & Health, Legal and Educational Services and Consulting & 11 & $42 \%$ & 15 & $58 \%$ & 26 & $100 \%$ \\
\hline & TOTAL & 387 & $41 \%$ & 546 & $59 \%$ & 933 & $100 \%$ \\
\hline \multicolumn{8}{|c|}{ Panel B Politically Connected Firms Sample Distribution (PCON) } \\
\hline \multirow{2}{*}{ SECTOR (SIC) } & \multirow{2}{*}{ INDUSTRY } & \multicolumn{2}{|c|}{ PCON } & \multicolumn{2}{|c|}{ NON-PCON } & \multicolumn{2}{|c|}{ TOTAL } \\
\hline & & $\mathbf{n}$ & $\%$ & n & $\%$ & $\mathbf{n}$ & $\%$ \\
\hline 0 & Agriculture, Forestry, and Fishing & 6 & $16 \%$ & 31 & $84 \%$ & 37 & $100 \%$ \\
\hline 1 & Mining & 48 & $32 \%$ & 104 & $68 \%$ & 152 & $100 \%$ \\
\hline 2 & Construction Industries & 80 & $36 \%$ & 145 & $64 \%$ & 225 & $100 \%$ \\
\hline 3 & Manufacturing & 55 & $36 \%$ & 97 & $64 \%$ & 152 & $100 \%$ \\
\hline 4 & Transportation, Communication and Utilities & 37 & $23 \%$ & 123 & $77 \%$ & 160 & $100 \%$ \\
\hline 5 & Wholesale and Retail Trade & 42 & $42 \%$ & 59 & $58 \%$ & 101 & $100 \%$ \\
\hline 7 & Services Industries & 32 & $40 \%$ & 48 & $60 \%$ & 80 & $100 \%$ \\
\hline \multirow[t]{2}{*}{8} & Health, Legal and Educational Services and Consulting & 18 & $69 \%$ & 8 & $31 \%$ & 26 & $100 \%$ \\
\hline & TOTAL & 318 & $34 \%$ & 615 & $66 \%$ & 933 & $100 \%$ \\
\hline \multicolumn{8}{|c|}{ Panel C Politically Connected Family Firms Sample Distribution $(F F \times P C O N)$} \\
\hline \multirow[t]{2}{*}{ SECTOR (SIC) } & \multirow[t]{2}{*}{ INDUSTRY } & \multicolumn{2}{|c|}{$F F \times P C O N$} & \multicolumn{2}{|c|}{$\begin{array}{c}\text { NON- } \\
F F \times P C O N\end{array}$} & \multicolumn{2}{|c|}{ TOTAL } \\
\hline & & $\mathbf{n}$ & $\%$ & n & $\%$ & $\mathbf{n}$ & $\%$ \\
\hline 0 & Agriculture, Forestry, and Fishing & 6 & $16 \%$ & 31 & $84 \%$ & 37 & $100 \%$ \\
\hline 1 & Mining & 19 & $13 \%$ & 133 & $88 \%$ & 152 & $100 \%$ \\
\hline 2 & Construction Industries & 19 & $8 \%$ & 206 & $92 \%$ & 225 & $100 \%$ \\
\hline 3 & Manufacturing & 21 & $14 \%$ & 131 & $86 \%$ & 152 & $100 \%$ \\
\hline 4 & Transportation, Communication and Utilities & 7 & $4 \%$ & 153 & $96 \%$ & 160 & $100 \%$ \\
\hline 5 & Wholesale and Retail Trade & 21 & $21 \%$ & 80 & $79 \%$ & 101 & $100 \%$ \\
\hline 7 & Services Industries & 7 & $9 \%$ & 73 & $91 \%$ & 80 & $100 \%$ \\
\hline \multirow[t]{2}{*}{8} & Health, Legal and Educational Services and Consulting & 11 & $42 \%$ & 15 & $58 \%$ & 26 & $100 \%$ \\
\hline & TOTAL & 111 & $12 \%$ & 822 & $88 \%$ & 933 & $100 \%$ \\
\hline
\end{tabular}

Notes: Panel A presents the sample of family firms (FF) and non-family firms; Panel B presents politically connected firms (PCON) and non-politically connected firms; Panel C presents politically connected family firms (FF $\times$ PCON) and non-politically connected family firms. All the sample is exhibited in the Panel A, B and C show 933 companies from all industrial sectors except industry with SIC 6 which is listed the in IDX (Indonesia Stock Exchange) in 2014-2016.

Table 2. Descriptive statistics $(n=933)$.

\begin{tabular}{lcccc}
\hline \multicolumn{1}{c}{ VARIABLES } & MEAN & MEDIAN & MINIMUM & MAXIMUM \\
\hline TOBINS_Q & 1.151 & 0.570 & 0.040 & 11.830 \\
FF & 0.328 & 0.000 & 0.000 & 1.000 \\
PCON & 0.341 & 0.000 & 0.000 & 1.000 \\
COMSIZE & 4.250 & 4.000 & 1.000 & 22.000 \\
INDCOM & 37.811 & 33.333 & 0.000 & 100.000 \\
DIRSIZE & 4.706 & 4.000 & 2.000 & 16.000 \\
INDDIR & 15.362 & 16.667 & 0.000 & 66.667 \\
FIRMAGE & 32.224 & 31.000 & 4.000 & 115.000 \\
T ASSET & 8.088 .000 .000 .000 & 2.268 .000 .000 .000 & 24.648 .960 & 86.080 .000 .000 .000 \\
MTB & 0.232 & 0.111 & -0.234 & 2.863 \\
CAPINT & 0.565 & 0.588 & 0.045 & 0.979 \\
GROWTH & 0.092 & 0.052 & -0.645 & 1.523 \\
LEV & 0.555 & 0.501 & 0.031 & 4.431 \\
\hline
\end{tabular}

This table presents descriptive statistics result of variables research used in this study. This research uses 933 companies from all industries excluding the financial industry (SIC 6) which are listed in IDX (Indonesia Stock Exchange) for the period 2014-2016. 


\section{Generation of active family directors}

Not available

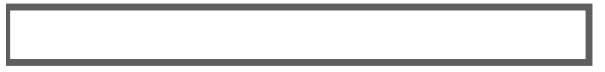

1st Generation

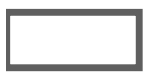

2nd Generation

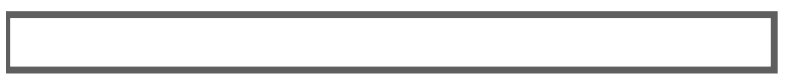

0

10

20

30

40

$\begin{array}{lll}50 & 60 \quad 70\end{array}$

Figure 2. Distribution of family generation in family firms with political connections.

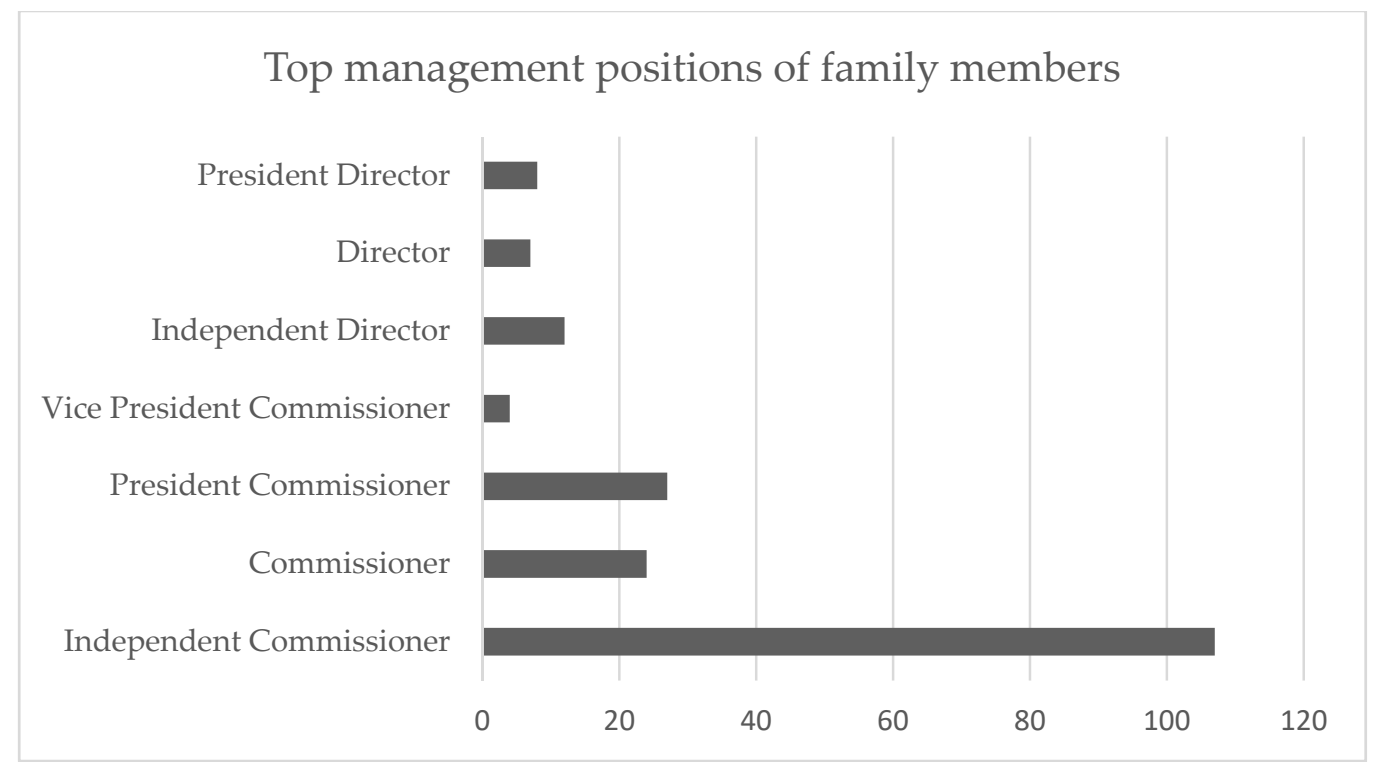

Figure 3. Distribution of political connections position in family firms with political connections.

Table 4 presents the Pearson's correlation matrix for all variables used in this study. This matrix measures the dependence and direction of the linear relationship between two random variables (real-valued vector) (Zhou et al. 2017). The positive or negative sign indicates the direction and strength of the relationship shown by the number of asterisks, which is defined as the level of significance. The results shows that family firms negatively associated to the firm performance. We also find that family firms are less likely to hire politically connected directors in their board. 
Table 3. Firm characteristics $(\mathrm{n}=933)$.

\begin{tabular}{lcccc}
\hline \multirow{2}{*}{ VARIABLES } & Family Firms & Non-Family Firms & Mean & Median \\
\cline { 2 - 5 } & $\mathbf{N}=\mathbf{3 8 7}$ & $\mathbf{N}=\mathbf{5 4 6}$ & t-value & z-value \\
\hline TOBINS_Q & 0.912 & 1.321 & $-3.397^{* * * *}$ & $-2.932^{* * *}$ \\
PCON & 0.287 & 0.379 & $-2.941^{* * *}$ & $-2.929^{* * *}$ \\
COMSIZE & 4.137 & 4.330 & -1.487 & $-2.295^{* *}$ \\
INDCOM & 37.556 & 37.992 & -0.481 & -0.722 \\
DIRSIZE & 4.791 & 4.647 & 1.109 & 1.377 \\
INDDIR & 14.739 & 15.803 & -1.103 & -1.474 \\
FIRMAGE & 2.528 & 2.493 & 0.681 & 0.774 \\
FIRMSIZE & 458.393 & 475.170 & $-3.487^{* * *}$ & $-3.731^{* * *}$ \\
MTB & 0.185 & 0.264 & $-2.845^{* * *}$ & $-2.122^{* *}$ \\
CAPINT & 0.541 & 0.582 & $-2.646^{* * *}$ & $-2.887^{* * *}$ \\
GROWTH & 0.097 & 0.089 & 0.452 & 0.790 \\
LEV & 0.522 & 0.578 & $-1.821^{*}$ & -0.533 \\
\hline
\end{tabular}

This table presents firm characteristics result of variables research used in this study. This research used 933 companies from all industries except the financial industry (SIC 6) which are listed in the IDX (Indonesia Stock Exchange) in 2014-2016. ${ }^{*} \mathrm{z}<1.640,{ }^{* *} \mathrm{z}<1.960,{ }^{* * *} \mathrm{z}<2.570$, significant in $10 \%, 5 \%$ and $1 \%$.

In the first hypothesis, we predict that firms with family ownerships are more likely to have a lower performance than firms without family ownership. To test this hypotesis, we use an OLS regression by constructing Equation (1). In this model, we include a set of control variables following the previous studies Harymawan and Nowland (2016); Harymawan et al. (2017). We also control for year and industry fixed effects. The detail of Equation (1) is presented as follows:

$$
\begin{gathered}
\text { TOBINS_Q }=\alpha+\beta 1 F F+\beta 2 P C O N+\beta 3 C O M S I Z E+\beta 4 I N D C O M+\beta 5 D I R S I Z E+ \\
\beta 6 I N D D I R+\beta 7 F I R M A G E+\beta 8 F I R M S I Z E+\beta 9 M T B+\beta 10 C A P I N T+\beta 11 G R O W T H+ \\
\beta 12 L E V+Y E A R \mathcal{E} \text { INDUSTRY FIXED EFFECTS }+\varepsilon
\end{gathered}
$$

Table 5 presents the results of OLS regression to test the hypothesis 1 . In the specification 1 we use family firms (FF) proxy constructed by Zhou et al. (2017). The coefficient of $F F$ shows -0.147 and is significant in the 5 percent level $(t=-2.52)$. This findings imply that firms with family ownership have a lower firm performance relative to firms without family ownership. As a robustnest test, we conduct the an additional OLS regression test as shown in specification 2. In this specification, we use an alternative measure of family firms based on Cheng (2014). Using this alternative proxy of family firms, the result is hold. The coefficient of $F F$ is -0.100 and significant in the 10 percent level $(t=-1.80)$. However, the regression results show that there is no significant association between political connections and firm performance.

In the second hypothesis, we examine whether and how the political connections affect the negative associations between family firms and company performance. To test the hypothesis, we formulate equation regression 2 as follows:

$$
\begin{gathered}
\text { TOBINS_Q }=\alpha+\beta 1 F F x P C O N+\beta 2 F F+\beta 3 P C O N+\beta 4 C O M S I Z E+\beta 5 I N D C O M+ \\
\beta 6 D I R S I Z E+\beta \text { IINDDIR }+\beta 8 F I R M A G E+\beta 9 F I R M S I Z E+\beta 10 M T B+\beta 11 C A P I N T+ \\
\beta 12 G R O W T H+\beta 13 L E V+Y E A R \mathcal{E} \text { INDUSTRY FIXED EFFECS }+\varepsilon
\end{gathered}
$$


Table 4. Pearson correlations ( $\mathrm{n}=933)$.

\begin{tabular}{|c|c|c|c|c|c|c|c|c|c|c|c|c|c|}
\hline & [1] & [2] & [3] & [4] & [5] & [6] & [7] & [8] & [9] & [10] & [11] & [12] & [13] \\
\hline [1] TOBINS_Q & 1.000 & & & & & & & & & & & & \\
\hline [2] $F F$ & $\begin{array}{c}-0.111^{* * *} \\
(0.001)\end{array}$ & 1.000 & & & & & & & & & & & \\
\hline [3] PCON & $\begin{array}{c}0.052 \\
(0.116)\end{array}$ & $\begin{array}{c}-0.096^{* * *} \\
(0.003)\end{array}$ & 1.000 & & & & & & & & & & \\
\hline [4] COMSIZE & $\begin{array}{c}0.090 * * * \\
(0.006)\end{array}$ & $\begin{array}{l}-0.049 \\
(0.137)\end{array}$ & $\begin{array}{c}0.286^{* * * *} \\
(0.000)\end{array}$ & 1.000 & & & & & & & & & \\
\hline [5] INDCOM & $\begin{array}{l}-0.051 \\
(0.121)\end{array}$ & $\begin{array}{l}-0.016 \\
(0.631)\end{array}$ & $\begin{array}{c}0.084^{* *} \\
(0.010)\end{array}$ & $\begin{array}{c}0.031 \\
(0.339)\end{array}$ & 1.000 & & & & & & & & \\
\hline [6] DIRSIZE & $\begin{array}{c}0.029 \\
(0.385)\end{array}$ & $\begin{array}{c}0.036 \\
(0.268)\end{array}$ & $\begin{array}{c}0.240^{* * * *} \\
(0.000)\end{array}$ & $\begin{array}{c}0.467^{* * *} \\
(0.000)\end{array}$ & $\begin{array}{c}0.020 \\
(0.540)\end{array}$ & 1.000 & & & & & & & \\
\hline [7] INDDIR & $\begin{array}{c}0.049 \\
(0.131)\end{array}$ & $\begin{array}{l}-0.036 \\
(0.271)\end{array}$ & $\begin{array}{l}-0.041 \\
(0.215)\end{array}$ & $\begin{array}{c}-0.123^{* * *} \\
(0.000)\end{array}$ & $\begin{array}{c}0.170^{* * * *} \\
(0.000)\end{array}$ & $\begin{array}{c}-0.259 * * * \\
(0.000)\end{array}$ & 1.000 & & & & & & \\
\hline [8] FIRMAGE & $\begin{array}{c}0.043 \\
(0.187)\end{array}$ & $\begin{array}{c}0.022 \\
(0.496)\end{array}$ & $\begin{array}{c}0.012 \\
(0.712)\end{array}$ & $\begin{array}{c}0.069^{* *} \\
(0.034)\end{array}$ & $\begin{array}{l}-0.049 \\
(0.134)\end{array}$ & $\begin{array}{c}0.032 \\
(0.332)\end{array}$ & $\begin{array}{c}-0.144^{* * *} \\
(0.000)\end{array}$ & 1.000 & & & & & \\
\hline [9] FIRMSIZE & $\begin{array}{c}-0.054^{*} \\
(0.098)\end{array}$ & $\begin{array}{c}-0.114^{* * *} \\
(0.001)\end{array}$ & $\begin{array}{c}0.287^{* * * *} \\
(0.000)\end{array}$ & $\begin{array}{c}0.520^{* * *} \\
(0.000)\end{array}$ & $\begin{array}{l}0.055^{*} \\
(0.092)\end{array}$ & $\begin{array}{c}0.547^{* * *} \\
(0.000)\end{array}$ & $\begin{array}{c}-0.142 * * * \\
(0.000)\end{array}$ & $\begin{array}{c}-0.062 * \\
(0.056)\end{array}$ & 1.000 & & & & \\
\hline [10] MTB & $\begin{array}{c}0.815^{* * *} \\
(0.000)\end{array}$ & $\begin{array}{c}-0.093 * * * \\
(0.005)\end{array}$ & $\begin{array}{c}0.076 * * \\
(0.020)\end{array}$ & $\begin{array}{c}0.099^{* * *} \\
(0.003)\end{array}$ & $\begin{array}{c}-0.084^{* *} \\
(0.010)\end{array}$ & $\begin{array}{c}0.044 \\
(0.182)\end{array}$ & $\begin{array}{c}0.018 \\
(0.573)\end{array}$ & $\begin{array}{c}0.008 \\
(0.808)\end{array}$ & $\begin{array}{c}0.021 \\
(0.513)\end{array}$ & 1.000 & & & \\
\hline [11] CAPINT & $\begin{array}{l}-0.017 \\
(0.594)\end{array}$ & $\begin{array}{c}-0.086^{* * *} \\
(0.008)\end{array}$ & $\begin{array}{c}0.010 \\
(0.764)\end{array}$ & $\begin{array}{l}0.060^{*} \\
(0.068)\end{array}$ & $\begin{array}{c}0.078^{* *} \\
(0.018)\end{array}$ & $\begin{array}{c}0.023 \\
(0.484)\end{array}$ & $\begin{array}{c}0.028 \\
(0.389)\end{array}$ & $\begin{array}{c}-0.174^{* * * *} \\
(0.000)\end{array}$ & $\begin{array}{c}0.212^{* * * *} \\
(0.000)\end{array}$ & $\begin{array}{c}0.023 \\
(0.488)\end{array}$ & 1.000 & & \\
\hline [12] GROWTH & $\begin{array}{l}-0.014 \\
(0.679)\end{array}$ & $\begin{array}{c}0.015 \\
(0.651)\end{array}$ & $\begin{array}{c}0.025 \\
(0.452)\end{array}$ & $\begin{array}{c}0.066^{* *} \\
(0.044)\end{array}$ & $\begin{array}{l}-0.048 \\
(0.141)\end{array}$ & $\begin{array}{c}0.027 \\
(0.406)\end{array}$ & $\begin{array}{c}-0.069^{* *} \\
(0.035)\end{array}$ & $\begin{array}{c}-0.104 * * * \\
(0.001)\end{array}$ & $\begin{array}{c}0.101^{* * *} \\
(0.002)\end{array}$ & $\begin{array}{c}0.045 \\
(0.169)\end{array}$ & $\begin{array}{l}-0.008 \\
(0.802)\end{array}$ & 1.000 & \\
\hline [13] $L E V$ & $\begin{array}{c}0.011 \\
(0.747)\end{array}$ & $\begin{array}{l}-0.060^{*} \\
(0.069)\end{array}$ & $\begin{array}{c}0.032 \\
(0.333)\end{array}$ & $\begin{array}{c}-0.102 * * * * \\
(0.002)\end{array}$ & $\begin{array}{c}0.108^{* * *} \\
(0.001)\end{array}$ & $\begin{array}{c}-0.089 * * * \\
(0.007)\end{array}$ & $\begin{array}{c}-0.072^{* *} \\
(0.027)\end{array}$ & $\begin{array}{l}0.054^{*} \\
(0.100)\end{array}$ & $\begin{array}{c}-0.088^{* * *} \\
(0.007)\end{array}$ & $\begin{array}{l}-0.048 \\
(0.143)\end{array}$ & $\begin{array}{c}0.128^{* * * *} \\
(0.000)\end{array}$ & $\begin{array}{c}-0.074^{* *} \\
(0.023)\end{array}$ & 1.000 \\
\hline
\end{tabular}

listed in the IDX (Indonesia Stock Exchange) in 2014-2016. ${ }^{*} p<0.1{ }^{* *} p<0.05,{ }^{* * *} p<0.01$, significant in 10\%, 5\% and $1 \%$. 
Table 5. Regression results of family firms and politically connected firms on firm performance.

\begin{tabular}{|c|c|c|}
\hline \multirow{2}{*}{ VARIABLES } & \multicolumn{2}{|c|}{ TOBINS_Q } \\
\hline & (1) & (2) \\
\hline$F F$ & $\begin{array}{c}-0.147^{* *} \\
(-2.52)\end{array}$ & $\begin{array}{c}-0.100 * \\
(-1.80)\end{array}$ \\
\hline PCON & $\begin{array}{l}-0.049 \\
(-0.64)\end{array}$ & $\begin{array}{l}-0.052 \\
(-0.68)\end{array}$ \\
\hline COMSIZE & $\begin{array}{c}0.060 * * * \\
(3.17)\end{array}$ & $\begin{array}{c}0.061^{* * *} \\
(3.18)\end{array}$ \\
\hline INDCOM & $\begin{array}{l}0.001 \\
(0.28)\end{array}$ & $\begin{array}{l}0.001 \\
(0.30)\end{array}$ \\
\hline DIRSIZE & $\begin{array}{c}0.041^{* *} \\
(1.96)\end{array}$ & $\begin{array}{l}0.040 * \\
(1.91)\end{array}$ \\
\hline INDDIR & $\begin{array}{c}0.005^{*} \\
(1.77)\end{array}$ & $\begin{array}{l}0.005^{*} \\
(1.72)\end{array}$ \\
\hline FIRMAGE & $\begin{array}{l}0.051 \\
(1.11)\end{array}$ & $\begin{array}{l}0.051 \\
(1.11)\end{array}$ \\
\hline FIRMSIZE & $\begin{array}{c}-0.003^{* * *} \\
(-3.19)\end{array}$ & $\begin{array}{c}-0.003^{* * *} \\
(-3.09)\end{array}$ \\
\hline MTB & $\begin{array}{c}3.497 * * * \\
(17.72)\end{array}$ & $\begin{array}{c}3.508^{* * *} \\
(17.76)\end{array}$ \\
\hline CAPINT & $\begin{array}{l}-0.171 \\
(-1.03)\end{array}$ & $\begin{array}{l}-0.172 \\
(-1.02)\end{array}$ \\
\hline GROWTH & $\begin{array}{l}-0.195 \\
(-1.18)\end{array}$ & $\begin{array}{l}-0.199 \\
(-1.21)\end{array}$ \\
\hline$L E V$ & $\begin{array}{l}0.192 \\
(0.85)\end{array}$ & $\begin{array}{l}0.195 \\
(0.85)\end{array}$ \\
\hline CONSTANT & $\begin{array}{c}0.836^{* *} \\
(2.54)\end{array}$ & $\begin{array}{c}0.750^{* *} \\
(2.34)\end{array}$ \\
\hline Year Dummies & Included & Included \\
\hline Industry Dummies & Included & Included \\
\hline R-Squared & 0.686 & 0.685 \\
\hline Number of Observation & 933 & 933 \\
\hline
\end{tabular}

This table presents regression result of family firms and politically connected firms on firm performance. This research use 933 companies from all industries except the financial industry (SIC 6) which are listed in the IDX (Indonesia Stock Exchange) from 2014 to $2016{ }^{*}, * *$, and ${ }^{* * *}$ is significant in $10 \%, 5 \%$ and $1 \%$, respectively.

Table 6 presents the results on the relationship between family firms and political connections on firm performance. In specification 1, we find that the coefficient of FFxPCON is 0.255 and significant in the 10 percent level $(t=1.79)$. This finding shows that a firm with family ownership which afiliated to political connections has better performance relative to others. We also find that the coefficient of $F F$ is -0.232 and significant in the 1 percent level $(t=-3.01)$. This result shows that family firms without political connections has lower performance than other firms. In addition, the result shows that PCON (non-family firms with political connections) is not significantly related to performance. Furthermore, we also conducted an additional test using an alternative proxy of family firms using the definition from Cheng (2014). As shown in specification 2, we find consistent results that firms with family ownership which have politically connected directors will have higher performance relative to other firms. Overal, the results indicate that in Indonesia, establishing political connections for family firm could improve the performance of family firms which support our hypothesis. For companies, the findings of this study suggest that family firms in Indonesia might consider political connections as one of potential resources to improve the performance of the firms. 
Table 6. Regression result of the interaction of family firms and politically connected firms on firm performance.

\begin{tabular}{|c|c|c|}
\hline \multirow{2}{*}{ VARIABLES } & \multicolumn{2}{|c|}{ TOBINS_Q } \\
\hline & (1) & (2) \\
\hline FFXPCON & $\begin{array}{c}0.255 * \\
(1.79)\end{array}$ & $\begin{array}{c}0.359^{* *} \\
(2.55)\end{array}$ \\
\hline$F F$ & $\begin{array}{c}-0.232 * * * \\
(-3.01)\end{array}$ & $\begin{array}{c}-0.207^{* * *} \\
(-2.92)\end{array}$ \\
\hline PCON & $\begin{array}{l}-0.147 \\
(-1.31)\end{array}$ & $\begin{array}{l}-0.152 \\
(-1.53)\end{array}$ \\
\hline COMSIZE & $\begin{array}{c}0.059 * * * \\
(3.16)\end{array}$ & $\begin{array}{c}0.059^{* * *} \\
(3.14)\end{array}$ \\
\hline INDCOM & $\begin{array}{l}0.001 \\
(0.32)\end{array}$ & $\begin{array}{l}0.001 \\
(0.29)\end{array}$ \\
\hline DIRSIZE & $\begin{array}{c}0.041^{* *} \\
(1.97)\end{array}$ & $\begin{array}{l}0.041 \text { * } \\
(1.95)\end{array}$ \\
\hline INDDIR & $\begin{array}{c}0.005^{*} \\
(1.70)\end{array}$ & $\begin{array}{l}0.005 \\
(1.64)\end{array}$ \\
\hline FIRMAGE & $\begin{array}{c}0.052 \\
(1.13)\end{array}$ & $\begin{array}{l}0.055 \\
(1.20)\end{array}$ \\
\hline FIRMSIZE & $\begin{array}{c}-0.003^{* * *} \\
(-3.13)\end{array}$ & $\begin{array}{c}-0.003^{* * *} \\
(-3.06)\end{array}$ \\
\hline MTB & $\begin{array}{c}3.500 * * * \\
(17.77)\end{array}$ & $\begin{array}{c}3.506^{* * *} \\
(17.72)\end{array}$ \\
\hline CAPINT & $\begin{array}{l}-0.199 \\
(-1.17)\end{array}$ & $\begin{array}{l}-0.204 \\
(-1.21)\end{array}$ \\
\hline GROWTH & $\begin{array}{l}-0.197 \\
(-1.19)\end{array}$ & $\begin{array}{l}-0.202 \\
(-1.23)\end{array}$ \\
\hline$L E V$ & $\begin{array}{l}0.190 \\
(0.84)\end{array}$ & $\begin{array}{l}0.196 \\
(0.86)\end{array}$ \\
\hline CONSTANT & $\begin{array}{c}0.831^{* *} \\
(2.53)\end{array}$ & $\begin{array}{c}0.745^{* *} \\
(2.33)\end{array}$ \\
\hline Year Dummies & Included & Included \\
\hline Industry Dummies & Included & Included \\
\hline R-Squared & 0.687 & 0.687 \\
\hline Number of Observation & 933 & 933 \\
\hline
\end{tabular}

This table presents regression results of the interaction of family firms and politically connected firms on firm performance. This research used 933 companies from all industries excluding the financial industry (SIC 6) which are listed in IDX (Indonesia Stock Exchange) from 2014 to 2016 . ***, and ${ }^{* * *}$ is significant in 10\%, 5\% and 1\%, respectively.

\section{Discussion and Conclusions}

This study sheds light on the role of political connections on the relationship between familiy firms and firm performance in Indonesia. Our findings confirm the negative relationship between family firms and firm performance. As a country which has significant political influence in business decision making, we further demonstrate that establishing political connections for family firms in Indonesia will enhance the performance of the firms. These findings strenghten prior findings which documents the positive associations between political connections and firm performance. The results of this study should be treated with caution since this study defines political connections using the politically exposed person (PEP) definition based on Indonesian banking regulation. This may underestimate the value political connections in Indonesia. For the future avenue of this research, it will be interesting to examine whether these relationships hold or change as the political power map changes.

Author Contributions: Conceptualization, I.H., M.N., and D.S.; Data curation, D.S.; Formal analysis, I.H., M.N. and D.S.; Methodology, I.H.; Software, I.H.; Supervision, I.H., M.N. and M.M.; Validation, I.H., M.N. and M.M.; Visualization, I.H. and D.S.; Writing-original draft, D.S.; Writing-review and editing, I.H. 
Funding: This project has received partial funding from the Universitas Airlangga under the "Riset Mandat" scheme in the 2018 .

Conflicts of Interest: The authors declare no conflict of interest.

\section{Appendix A}

Table A1. Variable definitions.

\begin{tabular}{|c|c|c|c|}
\hline Variables & Definition & Measurement & Data Sources \\
\hline \multicolumn{4}{|c|}{ Dependent Variable-Firm Performance } \\
\hline TOBINS_Q & Tobin's Q & $\begin{array}{l}\text { Market value of equity and book value of liabilities divided by } \\
\text { total asset. (Muttakin et al. 2015) }\end{array}$ & ORBIS \\
\hline \multicolumn{4}{|c|}{ Independent Variables } \\
\hline FF (Zhou) & Family Firm & $\begin{array}{l}\text { Dummy variable, } 1 \text { for family firm and } 0 \text { otherwise. In this } \\
\text { research, family firm is defined from position in director or } \\
\text { commissioner held by more than } 1 \text { member of family in same firm } \\
\text { (same family member marked from the same surname) and from } \\
\text { direct ownership of company share minimum } 5 \% \text {. } \\
\text { (Zhou et al. 2017) }\end{array}$ & $\begin{array}{l}\text { IDX ICMD from in } \\
\text { 2014-2016 }\end{array}$ \\
\hline FF (Cheng) & Family Firm & $\begin{array}{l}\text { Dummy variable, } 1 \text { for family firm and } 0 \text { otherwise. In this } \\
\text { research, family firm is defined from position in director or } \\
\text { commissioner held by more than } 1 \text { member of family in same firm } \\
\text { (same family member marked from the same surname). } \\
\text { (Cheng 2014) }\end{array}$ & $\begin{array}{l}\text { IDX ICMD from in } \\
\text { 2014-2016 }\end{array}$ \\
\hline PCON & $\begin{array}{l}\text { Politically } \\
\text { connected firm }\end{array}$ & $\begin{array}{l}\text { Dummy variable, } 1 \text { for politically connected firm and } 0 \text { otherwise. } \\
\text { Politically connected firm is defined from political experiences by } \\
\text { commissioner or director which meet PEP (politically exposed } \\
\text { person) criteria. }\end{array}$ & $\begin{array}{l}\text { IDX Financial } \\
\text { Report and Annual } \\
\text { Report in } \\
\text { 2014-2016 }\end{array}$ \\
\hline \multicolumn{4}{|l|}{ Control Variables } \\
\hline COMSIZE & Commissioner size & $\begin{array}{l}\text { Total commissioner in company include independent or } \\
\text { non-affiliated commissioner in a year. }\end{array}$ & $\begin{array}{l}\text { IDX Financial } \\
\text { Report in } \\
\text { 2014-2016 }\end{array}$ \\
\hline INDCOM & $\begin{array}{l}\text { Independent } \\
\text { commissioner }\end{array}$ & $\begin{array}{l}\text { Percentage of Independent commissioner compared with total } \\
\text { commissioner in a year. }\end{array}$ & $\begin{array}{l}\text { IDX Financial } \\
\text { Report in } \\
2014-2016\end{array}$ \\
\hline DIRSIZE & Director size & $\begin{array}{l}\text { Total director in company, include independent or non-affiliated } \\
\text { director in a year. }\end{array}$ & $\begin{array}{l}\text { IDX Financial } \\
\text { Report in } \\
\text { 2014-2016 }\end{array}$ \\
\hline INDDIR & $\begin{array}{l}\text { Independent } \\
\text { director }\end{array}$ & $\begin{array}{l}\text { Percentage of Independent director compared with total director } \\
\text { in a year. }\end{array}$ & $\begin{array}{l}\text { IDX Financial } \\
\text { Report in } \\
2014-2016\end{array}$ \\
\hline FIRMAGE & Firm age & $\begin{array}{l}\text { Natural logarithm of firm age that counted from incorporate date } \\
\text { (Muttakin et al. 2015) }\end{array}$ & ORBIS \\
\hline FIRMSIZE & Firm size & $\begin{array}{l}\text { Quadrate from natural logarithm of total assets. } \\
(\ln (\text { TOTAL ASSET }))^{2} \\
\text { (Muttakin et al. 2015) }\end{array}$ & ORBIS \\
\hline MTB & $\begin{array}{l}\text { Market to book } \\
\text { ratio }\end{array}$ & $\begin{array}{l}\text { Ratio of Market value of equity compared to book value of equity. } \\
\text { (Xu et al. 2015) }\end{array}$ & ORBIS \\
\hline CAPINT & Capital intensity & Ratio of fixed assets compared to total assets (Wu et al. 2012) & ORBIS \\
\hline GROWTH & Firm growth & $\begin{array}{l}\text { Ratio of asset growth in a year. } \\
\frac{\text { TOTAL ASSET } \mathrm{t}-\text { TOTAL ASSET }(\mathrm{t}-1)}{\text { TOTAL ASSET }(\mathrm{t}-1)} \\
\text { (Muttakin et al. 2015) }\end{array}$ & ORBIS \\
\hline LEV & Leverage & Ratio of total liabilities to total assets (Xu et al. 2015) & ORBIS \\
\hline SIC & SIC Code & $\begin{array}{l}\text { Standard Industrial Classification Code are four-digit numerical } \\
\text { codes assigned by the U.S. government to business establishments } \\
\text { to identify the primary business of the establishment. }\end{array}$ & ORBIS \\
\hline
\end{tabular}

\section{References}

Adhikari, Ajay, Chek Derashid, and Hao Zhang. 2006. Public policy, political connections, and effective tax rates: Longitudinal evidence from Malaysia. Journal of Accounting and Public Policy 25: 574-95. [CrossRef]

Anderson, Ronald C., and David M. Reeb. 2003. Founding-family ownership and firm performance: Evidence from the S\&P 500. The Journal of Finance 58: 1301-28. [CrossRef] 
Benjamin, Samuel Jebaraj, Shaista Wasiuzzaman, Helen Mokhtarinia, and Niloufar Rezaie Nejad. 2016. Family ownership and dividend payout in Malaysia. International Journal of Managerial Finance 12: 314-34. [CrossRef]

Beuren, Ilse Maria, Leandro Politelo, and José Augusto Sousa Martins. 2016. Influence of Family Ownership on Company Performance. International Journal of Managerial Finance 12: 654-72. [CrossRef]

Boubakri, Narjess, Omrane Guedhami, Dev Mishra, and Walid Saffar. 2012. Political connections and the cost of equity capital. Journal of Corporate Finance 18: 541-59. [CrossRef]

Cheng, Qiang. 2014. Family firm research-A review. China Journal of Accounting Research 7: 149-63. [CrossRef]

Claessens, Stijn, Simeon Djankov, and Larry H. P. Lang. 2000. The separation of ownership and control in East Asian Corporations. Journal of Financial Economics 58: 81-112. [CrossRef]

Cucculelli, Marco, and Giacinto Micucci. 2008. Family succession and firm performance: Evidence from Italian family firms. Journal of Corporate Finance 14: 17-31. [CrossRef]

Ding, Shujun, Chunxin Jia, Zhenyu Wu, and Xiaoqing Zhang. 2014. Executive political connections and firm performance: Comparative evidence from privately-controlled and state-owned enterprises. International Review of Financial Analysis 36: 153-67. [CrossRef]

Eddleston, Kimberly A., Franz Willi Kellermanns, and Ravi Sarathy. 2007. Resource configuration in family firms: Linking resources, strategic planning and technological opportunities to performance. Journal of Management Studies 45: 26-50. [CrossRef]

Faccio, Mara. 2006. Politically connected firms. The American Economic Review 96: 369-86. [CrossRef]

Fisman, Raymond. 2001. Estimating the value of political connections. American Economic Review 91: 1095-102. [CrossRef]

Gray, Stephen, Iman Harymawan, and John Nowland. 2016. Political and government connections on corporate boards in Australia: Good for business? Australian Journal of Management 41: 3-26. [CrossRef]

Harymawan, Iman. 2018. Why do firms appoint former military personnel as directors? Evidence of loan interest rate in militarily connected firms in Indonesia. Asian Review of Accounting 26: 2-18. [CrossRef]

Harymawan, Iman, and John Nowland. 2016. Political connections and earnings quality. International Journal of Accounting \& Information Management. [CrossRef]

Harymawan, Iman, Dian Agustia, and Ardyan Kusuma Agung. 2017. Characteristics of politically connected firms in Indonesia. Problems and Perspectives in Management 15: 17-23. [CrossRef]

Harymawan, Iman, Mohammad Nasih, Melinda Cahyaning Ratri, and John Nowland. 2019. CEO busyness and firm performance: evidence from Indonesia. Heliyon 5: e01601. [CrossRef] [PubMed]

Hategan, Camelia-Daniela, Ruxandra-Ioana Curea-Pitorac, and Vasile-Petru Hategan. 2019. The Romanian Family Businesses Philosophy for Performance and Sustainability. Sustainability 11: 1715. [CrossRef]

Houston, Joel F., Liangliang Jiang, Chen Lin, and Yue Ma. 2014. Political connections and the cost of bank loans. Journal of Accounting Research 52: 193-243. [CrossRef]

Hung, Chi-Hsiou D., Yuxiang Jiang, Frank Hong Liu, Hong Tu, and Senyu Wang. 2017. Bank political connections and performance in China. Journal of Financial Stability 32: 57-69. [CrossRef]

Jara Bertin, Mauricio, and Félix J. López Iturriaga. 2014. Earnings management and the contest to the control: an international analysis of family-owned firms. Spanish Journal of Finance and Accounting/Revista Española de Financiación y Contabilidad 43: 355-79. [CrossRef]

Li, Hongbin, Lingsheng Meng, Qian Wang, and Li-An Zhou. 2008. Political connections, financing and firm performance: Evidence from Chinese private firms. Journal of Development Economics 87: 283-99. [CrossRef]

Maury, Benjamin. 2006. Family ownership and firm performance: Empirical evidence from Western European corporations. Journal of Corporate Finance 12: 321-41. [CrossRef]

McConaughy, Daniel L., Charles H. Matthews, and Anne S. Fialko. 2001. Founding family controlled firms: Performance, risk, and value. Journal of Small Business Management 39: 31-49. [CrossRef]

Mulyani, Evy, Harminder Singh, and Sagarika Mishra. 2016. Dividends, leverage, and family ownership in the emerging Indonesian market. Journal of International Financial Markets, Institutions and Money 43: 16-29. [CrossRef]

Muttakin, Mohammad Badrul, Reza M. Monem, Arifur Khan, and Nava Subramaniam. 2015. Family firms, firm performance and political connections: Evidence from Bangladesh. Journal of Contemporary Accounting $\mathcal{E}$ Economics. [CrossRef]

Naldi, Lucia, Mattias Nordqvist, Karin Sjöberg, and Johan Wiklund. 2007. Entrepreneurial orientation, risk taking, and performance in family firms. Family Business Review 20: 33-47. [CrossRef] 
Niessen, Alexandra, and Stefan Ruenzi. 2010. Political connectedness and firm performance: Evidence from Germany. German Economic Review 11: 441-64. [CrossRef]

Ramdani, Dendi, and Arjen van Witteloostuijn. 2010. The impact of board independence and CEO duality on firm performance: A quantile regression analysis for Indonesia, Malaysia, South Korea and Thailand. British Journal of Management 21: 607-27. [CrossRef]

Sánchez, Juan M., and Emircan Yurdagul. 2013. Why are corporations holding so much cash? The Regional Economist 21: 4-8.

Sciascia, Salvatore, and Pietro Mazzola. 2008. Family involvement in ownership and management: Exploring nonlinear effects on performance. Family Business Review 21: 331-45. [CrossRef]

Sraer, David, and David Thesmar. 2007. Performance and behavior of family firms: Evidence from the French stock market. Journal of the European Economic Association 5: 709-51. [CrossRef]

Untoro, Wisnu, Wulan Permatasari, Irwan Trinugroho, and Doddy Setiawan. 2017. Past performance, family business and CEO succession: The case of Indonesia. International Journal of Trade and Global Markets 10: 236-50. [CrossRef]

Villalonga, Belen, and Raphael Amit. 2006. How do family ownership, control and management affect firm value? Journal of Financial Economics 80: 385-417. [CrossRef]

Wang, Delu, Gang Ma, Xuefeng Song, and Yun Liu. 2016. Political connection and business transformation in family firms: Evidence from China. Journal of Family Business Strategy 7: 117-30. [CrossRef]

$\mathrm{Wu}$, Wenfeng, Chongfeng Wu, Chunyang Zhou, and Jun Wu. 2012. Political connections, tax benefits and firm performance: Evidence from China. Journal of Accounting and Public Policy 31: 277-300. [CrossRef]

Xu, Nianhang, Qingbo Yuan, Xuanyu Jiang, and Kam C. Chan. 2015. Founder's political connections, second generation involvement, and family firm performance: Evidence from China. Journal of Corporate Finance. [CrossRef]

Zhou, Haoyong, Fan He, and Yangbo Wang. 2017. Did family firms perform better during the financial crisis? new insights from the S\&P 500 firms. Global Finance Journal 33: 88-103. [CrossRef]

(C) 2019 by the authors. Licensee MDPI, Basel, Switzerland. This article is an open access article distributed under the terms and conditions of the Creative Commons Attribution (CC BY) license (http://creativecommons.org/licenses/by/4.0/). 